\title{
Collaborating Blended Learning Model into Content Representation Product Design at Eleventh Grade English Subjects
}

\author{
${ }^{1}$ Testiana Deni Wijayatiningsih, ${ }^{2}$ Nanda Eka Yuniarti \\ ${ }^{1,2}$ Universitas Muhammadiyah Semarang, Semarang \\ testiana@unimus.ac.id
}

Article History: Submitted June 22 ${ }^{\text {nd }}, 2019$; Accepted June $28^{\text {th }}, 2019$; Published July $5^{\text {th }}, 2019$

\begin{abstract}
The design development of the CoRe (Content Representation) model is another model of the lesson plan that is applied using the Blended learning model. The purpose of this study is to design and validate the suitability of CoRe products with the high school syllabus. The method used by using descriptive quantitative method based on the stages of $\mathrm{R}$ and D (Research and Development), especially in seven stages, namely; research and data collection, planning, initial product development, piloting and refinement of initial products, testing and refinement of products that have been refined for final product testing, disseminated, implemented, and institutionalized. Besides, this study limits the stages until the fourth stages, trial and refinement of initial products in order to achieve the best product. The results obtained are the valid lesson plan design plan with CoRe used in teaching English to high school class XI students. The activity of students also increased by showing a positive response and the results of the daily pre-test and post-test exercise improved well. In addition, the CoRe Model can also be used to help teachers improve Pedagogical Content Knowledge in the teaching and learning process.
\end{abstract}

Keywords: blended learning; content representation product; English subject

\begin{abstract}
Abstrak. Pengembangan desain model CoRe (Content Representation) merupakan model lain dari lesson plan yang diaplikasi menggunakan model Blended learning. Tujuan dari penelitian ini yaitu mendesain dan memvalidasi kesesuaian produk CoRe dengan silabus Sekolah Menengah Atas. Metode yang digunakan dengan menggunakan metode descriptive kuantitatif berdasarkan tahapan $R$ and $D$ (Research and Development) khususnya pada tujuh tahap yakni; penelitian dan pengumpulan data, perencanaan, pengembangan produk awal , uji coba dan penyempurnaan produk awal, uji coba dan penyempurnaan produk yang telah disempurnakan pengujian produk akhir, serta didiseminasi, implementasi dan instituisionalisasi. Selain itu, penelitian ini membatasi hanya sampai tahap kelima yakni uji coba dan penyempurnaan produk. Hasil yang diperoleh yaitu model perancangan lesson plan dengan CoRe valid digunakan dalam mengajar bahasa Inggris pada siswa kelas XI SMA. Keaktifan siswa pun meningkat dengan menunjukkan respon positif dan hasil pre test dan post test latihan ulangan harian meningkat dengan baik. Selain itu, Model CoRe juga dapat digunakan membantu guru dalam meningkatkan Pedagogical Content Knowledge di dalam proses belajar mengajar.
\end{abstract}

Kata kunci: blended learning; content product representation; bahasa Inggris

\section{INTRODUCTION}

Teachers must have good competence with the disciplines they have in planning the learning process can be achieved. This achievement shows the professionalism of a 
teacher, these competencies include basic things as educators. In accordance with the opinion of Soedijarto (2008: 142) which states that the teacher's professional abilities include designing and planning learning programs, developing learning programs, managing the implementation of learning programs, assessing the process and results of learning and diagnosing factors that influence the success of the learning process. Based on the results of observations in SMA N 15 Semarang, the teachers, especially English teachers, prepared a learning design using the standardized Learning Planning (RPP) form from the Education Office and agencies. The design of learning planning should be arranged systematically so that it makes it easier for the teacher to teach while observing the learning process that occurs.

In fact, in SMA N 15 Semarang still used standardized RPP. In this case, we design the CoRe Product that can help the teacher to help plan a good learning process, observe the process and help plan research for the teacher as well as the use of online technology in learning. Many factors why CoRe products are considered easier and more specific media use. Technology media is one of the best ways to implement it. The suitability of the CoRe products produced will have an effect on the application in the classroom. This study wanted to find out whether the CoRe design of the product collaborated with the Blended learning validity method.

\section{Competence}

According to Mulyasa (2008: 38) competence is defined as knowledge, skills, and abilities that are mastered by someone who has become a part of him, so that he can do cognitive, affective, and psychomotor behaviors as well as possible. Furthermore, according to Law No. 14 of 2005 concerning Teachers and Lecturers article 10 paragraph (1) teacher competencies include pedagogical competencies, personality competencies, social competencies, and professional competencies obtained through professional education (Yamin, 2006).

\section{Pedagogical Content Knowledge (PCK)}

According to Koppelmann (2008: 23) PCK can be seen as an intersection between pedagogy and content. Therefore PCK is a practical way of knowing the subject matter used by teachers when they teach. PCK is a form of teacher's professional knowledge which is arranged differently from the knowledge of the subject matter of the teacher by combining between the Learning Design and pedagogical knowledge in enhancing the experience. Taconis and Jochems (2010: 18) suggest that "the points that are made by expert teachers are not born with PCK, and that it is a process for student teachers and new knowledge to be needed. become expert teachers in their field. According to Taconis and Jochems's statement that the instructor or not born with PCK capability, the ability to apply this competency is based on long hours so that the understanding of PCK takes a long time to adjust to the teaching skills and new knowledge needed to become teaching experts in their fields.

Many researchers in the field of education have examined pedagogical approaches to students, teachers and beginner teachers to assist in conceptualizing learning and increasing understanding of pedagogical content knowledge. A approach is said to be successful before conducting teaching and learning activities found in content representation or CoRe, which are made explicitly tailored to different dimensions, learning content and teaching and learning on specific topics. 


\section{CoRe (Content Representation)}

The application of one of the CoRe models to support the implementation of Pedagogical Content Knowledge to test the development of teaching professionalism in designing and implicating educational science to improve the development of learning tools to prepare for the development of Pedagogical Content Knowledge in future teaching (Abell, Park Rogers, Hanuscin, Gagnon, \& Lee, in press, 2008: 11).

Indicators in making products that are tailored to the conditions for making CoRe products that have been made (Loughran, Mulhall \& Berry, 2004, 2008). Increasing understanding of learning instruments is called "Content Representation" or CoRe, which is made in a different dimension, presentation, knowledge context, teaching and learning activities on special matters. CoRe is described in the form of a table, accompanied by the general ability of the instructor related to PCK according to the teaching process in each teaching material, consisting of five sub chapters of material with eight indicators of CoRe product in each row, arrangement adjusted for pedagogical questions in each sub-material.

Content Representation ( $\mathrm{CoRe}$ ) is one of the marking factors in effective activities in a teacher in achieving Pedagogical Content Knowledge (PCK). As an educator, of course, they must have the ability to make lesson plans by using CoRe (Content Representation) on English subjects. As it is known that the CoRe (Content Representation) learning design model is more widely used in designing learning in Natural Sciences subjects. The CoRe model is one model whose content is from learning devices (syllabus, RPP, textbooks (Student Worksheets), handouts / handbooks, media).

The CoRe model helps novice teachers develop learning tools by conceptually loading designs. In this case, science English subject and technology are as a unity in pedagogic provisions. The use of CoRe will make it easier for teachers to plan and deliver material in their entirety in the classroom that will give influence in teaching and learning the learning plan. The research was carried out by combining the results of CoRe products with blended learning. Blended learning will be adjusted to the learning material and the use of media in accordance with the method used.

\section{Blended Learning in English Teaching Learning Process}

According to Miarso (in Hariadi, 2000), learning resources can be divided into two types namely (1) planned learning resources (by design) and (2) learning resources because they are used (by utilization). Learning resources by design are all sources that have specifically been developed as a component of the instructional system to provide directed and formal learning facilities. This learning source by design is deliberately made to be used in learning activities to achieve certain learning goals. Learning resources by this design such as textbooks, textbooks, slides, films, videos, programmed teaching materials, computerbased teaching programs etc. are specifically designed and made to achieve certain goals.

Learning resources by utilization are sources that are not specifically designed for learning purposes but can be found, applied and used for learning purposes.

This source of learning by utilization is not designed or intentionally made to achieve certain learning goals. This by Utilization learning source is already around, and at some point in certain conditions can be used to achieve certain learning goals. So this learning resource already exists, just use it to achieve certain learning goals. This by utilization 
learning resources such as markets, shops, museums, community leaders, magazines, newspapers, all information (data) on the internet network and so on.

The use of learning media today is not new, but one of the media that is very helpful in the teaching process in the classroom. According to Benthall (2008: 34), there are three concepts in blended learning, namely pedagogies, technology, and theories of learning. Pedagogies are changes in the learning paradigm from what used to be more learning center (teaching center learning paradigms) towards a new paradigm that is studentcentered (student centered learning paradigm). In pedagogies, there is also an increase in interaction between learners and learners, between students, students and learners with content, students and learners with other learning resources. In addition, there is also convergence between various methods, media, learning resources and other relevant learning environments. Technology in this case is using internet media, such as websites and blogs, chat, forums, teleconferences, audio and video in the blended learning method. Theories of Learning allow the emergence of new models in teaching and learning so that there are significant changes in the transformation of education or changes in paradigm.

In line with those explication, the term most commonly used to refer to any combination of face-to-face teaching with technology integration (online and offline activities/materials) called blended learning (Whittaker, 2013). It meant that collaborating online activities and face to face activities is similar to blending technology and teaching learning process in the classroom, such as applying Google classroom, e-learning, what app, instagram, etc.

The link between CoRe products and the use of technology especially blended learning model is very close. This is what underlies the making of lesson plans by combining both of them to achieve educator goals and expectations for students. The development of technology is not foreign to the world of education, that education will be flexible with developments towards progress. Technology media develops and widens insights and means that are good at mastering the material. Blended learning that is often encountered is by using websites, blogs and several electronic sources. The use of media such as projectors, speakers and laptops is often used by English teachers to hone students' listening, speaking and reading skills.

When viewed from the times and currently entering the millennial generation, it will look strange if learning is not adjusted to the habits of current students. The ease of delivering information is felt to be more effective and efficient as the main factor of learning.

\section{METHOD}

This research uses a combination method using quantitative descriptive method with several steps of the R and D method "Research and Development". According to Sugiyono (2013: 147) descriptive method is a method used to analyze data by describing or describing data that has been collected as it is without intending to make conclusions that apply to general or generalizations. As well as understanding according to Sugiyono (2013: 297) Research and Development research methods are research methods used to produce certain products, and test the effectiveness of these products.

Descriptive quantitative according to Sugiyono (2012: 7), quantitative research methods can be interpreted as research methods based on positivist philosophy, used to examine certain populations or samples. The sampling technique is generally done randomly, data 
collection uses research instruments, data analysis is quantitative or statistical in order to test the hypotheses that have been set. This study combines two methods that were proposed by Sukmadinata (2009: 61-66), the research strategy is one way to collect data that is the object, subject, variable, and problem studied so that the data is directed at the objectives to be achieved. While the Research and Development method has steps to carry out activities, but in this study only a few steps will be used. Steps of Research and Development research methods:

1. Research and Data Collection

2. Planning

3. Early Product Development

4. Trial and Refinement of Initial Products

5. Trial and improvement of products that have been refined

6. Final Product Testing

7. Dissemination, implementation and institutionalization

The research process using the Research and Development method only uses four steps of research. This is because there are several considerations that the research process is limited to testing the product model that has been made by the researcher. However, this does not reduce the results of the research process obtained by researchers to show the validity of a CoRe product. The steps for implementing the Research and Development method include; research and data collection, planning, initial product development, and product improvement trials. The indicator for validation the product can be seen in Table 1 .

\section{Table 1 Indicator Validation Product}

\begin{tabular}{cc}
\hline Value Range & Explanation \\
\hline $1 \leq \mathrm{x}<2$ & Invalid (the product has not been applied) \\
$2 \leq \mathrm{x}<3$ & Enough the product can be applied with many \\
$3 \leq \mathrm{x}<4$ & revisions) \\
\hline
\end{tabular}

\section{RESULTS AND DISCUSSION}

Based on the results of data collection which included questionnaires / product questionnaires validated by lecturers and teachers, the following results were obtained:

Table 2 Content Representation Product Data Validity

\begin{tabular}{cccccc}
\hline No & \multicolumn{1}{c}{ Statements } & $\begin{array}{c}\text { Validator } \\
\mathbf{1}\end{array}$ & $\begin{array}{c}\text { Validator } \\
\mathbf{2}\end{array}$ & $\begin{array}{c}\text { Avera } \\
\text { ge }\end{array}$ & Note \\
\hline 1 & CoRe Product Model & 4 & 4 & 4 & Valid \\
2 & $\begin{array}{l}\text { CoRe Collaboration } \\
\text { with } \\
\text { Teacher Competence }\end{array}$ & 3 & 3 & 3 & Valid \\
& & & & &
\end{tabular}


3 Product development is in accordance with PCK 4

4 Compatibility of content with learning material

$4 \quad 3$

Valid

material

5 Teachers can apply the model easily

6 Product conformity with the 2013 curriculum syllabus 3

7 Achievement of centralized learning 4

8 Structured learning indicators 3

9 Ease of observing student constraints 3

10 Systematic learning procedures Valid 3

$4 \quad 4$

$4 \quad 4$

Valid

Systematic learning procedures

3

In the discussion of the results of the study, ten aspects were used regarding the CoRe Product research that had been adjusted to the standards of evaluating the results of Content Representation products that had been adjusted to the provisions of the Content Representation model (Loughran, Mulhall \& Berry, 2004, 2008), as follows:

\section{CoRe Product Model}

The CoRe product model is another model of making lesson plans that are used by several instructors in classifying learning designs according to material needs. The design model of learning devices that is still in the process of development in the world of education. So that the implementation of optimization in making lesson plans in accordance with PCK is understood by each teacher. In accordance with what the validator 1 said about the CoRe product model that the author made said that the products made were good but must be adapted to the material, rules and syllabus.

Thus the CoRe model created by the author still needs improvement in connecting products with various sources of guidelines for making lesson plans. This research is because it uses the Student Worksheet / module that has relevance to the process of self-learning students and is inserted several things supporting learning from various sources. The existence of the Content Representing model provides the teacher's choice in making the teaching scenario more detailed. This is indicated by the two validators who support the existence of the CoRe model with further additions or improvements and can be applied in educational institutions.

\section{CoRe with Enhancing Teacher Competence}


Competency is generally obtained as time passes or is qualified in understanding the context of teaching. Where teaching is not only limited to the activity of transferring knowledge from the teacher or teacher to students. Behind the teaching activities in the classroom there are several things that the teacher must understand in planning, implementing and evaluating activities. It is not an easy thing for teachers to collaborate between competence or ability to make CoRe products a more systematic planning model. This is known from the validation process by the validator stating that the products produced are still considered suite or not so well known by the instructors from the segment of the secondary education school and have only just been developed by instructors of higher education. So the progress of the CoRe model requires foresight and further product introduction activities.

\section{Product development is in accordance with PCK}

Pedagogical Content Knowledge indicator in planning, implementing and evaluating the process of teaching and learning activities in the classroom. Validation results show that product development with appropriate rules is still in the moderate or good level. That the CoRe model still contains several things regarding appreciation, core, influence and expectations. It can be said that the product has used PCK guidelines but must be adapted to the 2013 curriculum for further improvement. Compliance with the guidelines is good.

\section{Compatibility of content with learning material}

As is known material also determines in the learning process in the classroom, such as methods and some things concerning teaching content. It is known that CoRe product has 8 parts of questions and several sub-chapters that are tailored to the target and teaching objectives regarding conformity with the material. This material is in accordance with the instructor's policies, what things are considered to be the focus, such as the example of tenses or Grammar material does require understanding, analysis and take a long time, the instructor may divide the sub-tenses into 3-4 parts (past tense, present tense, future tense, etc.) thus the teaching process has been structured and well organized as well as resources or media.

\section{Teachers can apply the model easily}

The model for making a lesson plan like this helps teachers to develop plans or scenarios more effectively. Because it doesn't take a long time, just plotting each question and adjusting it to the guidelines and learning material, this model is more effective for beginner teachers to plan activities because they are well structured. Teachers only focus on practices and guidelines for activity model scenarios, so PCK or Pedagogical Content Knowledge can go hand in hand with qualified teacher competency. With this model providing opportunities for developing novice teachers, however, the introduction of a further CoRe model for teachers or instructors among high school / vocational / MA / MAK teachers must be implemented.

\section{Product conformity with the 2013 curriculum syllabus}

Basically, the CoRe model is not only tied to the 2013 curriculum, but can be used for KTSP and KBK. Over time this model can represent the planning method of each teacher. Content Representation only regulates the model or way of presenting RPP effectively, structured, so that it requires improvement with conformity with the 2013 Curriculum. 


\section{Achievement of centralized learning}

The advantage of using CoRe products in all aspects of planning, implementation and evaluation is shown in the results, making it easier for the teacher to identify difficulties, and mark learning for each individual. There is a learning outcomes or expectations of each material. This makes it easy for teachers to map material, methods and make it easier for students to understand the material clearly.

\section{Structured Learning Indicators}

The learning system implemented by the instructor is adjusted to the syllabus guidelines, where the syllabus contains the core learning points of each meeting. This model has divided indicators into several sub-chapters that make the core material of teaching. Content that is made is not synchronous and in accordance with the indicators, the material and syllabus as a reference for teaching and learning, so that the assessment indicators are still unclear and specific. It requires improvement in conformity of guidelines, models and illustrations of activities.

\section{Ease of observing student constraints}

The development of this model is said to be an effective model in drafting learning devices. From this method model the teacher can classify and observe while evaluating student development while learning. Learning material is good so that the existence of the model makes it easy, effective, and efficient to be used by the instructor.

\section{Systematic learning procedures}

The learning process cannot be separated from the teaching scenario carried out by the teacher. There are many things that must be prepared in determining the steps in delivering the material, apperception and getting feedback from students. Here the teacher's skills begin to be tested to design the expected class so that the achievement of learning is said to be successful in the classroom.

\section{CoRe Product Development Results with Blended Learning}

Designing a lesson plan using CoRe product model is one combination between designing learning in the classroom by developing and adapting to the determined media technology or website using five basic concepts of using blended learning methods namely face-toface learning, independent learning, collaboration, assessment, learning support . The design of the lesson plan using the CoRe model can help novice teachers design, observe, and evaluate teaching and learning activities easily. If you look at the syllabus and the content of the 2013 curriculum, it focuses on activities for students or students based learning. Teachers as facilitators in learning activities, From the digital era, every teacher and student must be qualified in using technology that will help learning in the classroom.

The researchers have designed the CoRe product with the object of eleventh grade students at SMA N 15 Semarang. The source of making CoRe product uses LKS (Student Worksheet) entitled Learning Module for English High School / Middle School and Vocational / MAK Class XI Semester 1 Based on Curriculum 2013 published by Viva Pakarindo. 
CoRe product is adjusted to the provisions for making tables consisting of 8 subassessment and content sections. CoRe products are made on the basis of each core of learning by describing each sub-chapter with the ability of the teacher to teach in the class or design class that will be created by the teacher itself. CoRe product can help teachers, especially beginner teachers, in arranging activities in each topic or topic of discussion. The making of CoRe Product is tailored to the development of pedagogical content knowledge (PCK) so that in its implementation based on teaching tools such as syllabus, lesson plans, and books or teaching materials. CoRe products also help beginner teachers in designing classroom teaching and what learning plans to expect.

Validation is carried out by two educators with English language teaching backgrounds in high school and university. The high school teacher who reviewed the results of the research on CoRe products was still unfamiliar and was not familiar with English teachers. This product is a product of development from the new pedagogical developments known by educators with a background in natural science. In general, the teaching plan contains several general things such as indicator competencies, basic competencies or standards for making RPP that have been set by the government. Unlike the CoRe product, which only makes lesson plans standardized by Hume and Berry (2010) which states that CoRe products are more effective in designing learning specifically on natural subjects.

\section{CONCLUSION}

Content Representation is one of the other models in designing the learning process that is considered dynamic, structured, effective and easy to understand for beginner teachers in modeling teaching in the classroom that must be adjusted to the guidelines for the design of learning devices, namely syllabus and 2013 curriculum guidelines. This CoRe model is usually used by instructors in Natural Education. The results of the validation of the product that have been designed by the researcher have received good feedback, but only have to be adjusted to the syllabus and guidelines for making other lesson plans. The results obtained from this study state that CoRe products are made valid in developing an English learning model of class XI that is collaborated with Blended learning methods so that this model can be used by teachers and instructors.

\section{REFERENCES}

Abell, S.K., Park Rogers, M.A., Hanuscin, D.L., Gagnon, M.J., \& Lee, M.H. (In press). Preparing the next generation of science teacher educators: A trajectory for developing PCK for teaching science teachers. Journal of Science Teacher Education.

Benthall, Nigel. 2008. Blended Learning: Setting the Course for the "Crew Change".

E. Mulyasa. 2008. Menjadi Guru Profesional Menciptakan Pembelajaran Kreatif dan Menyenangkan. Bandung : PT. Remaja Rosdakarya.

Hariadi, Bambang. 2000. Pemanfaatan Internet (SICYCA) Sebagai Sumber Belajar di STIKOM Surabaya. Tesis Tidak Diterbitkan. Universitas Negeri Malang

Hume, A. (2010). Cores as Tools for Promoting Pedagogical Content Knowledge of Novice Science Teachers. Chemistry Education in New Zealand May 2010 
Hume, A., \& berry, A. (2010). Constructing CoRes-a strategy for building pCk in preservice science teacher education. Research in Science Education, 41(3), 341-355. doi: 10.1007/s11165-010-9168-3.

Loughran, J., mullhall, p., \& berry, A. (2004). in search of pedagogical content knowledge in science: developing ways of articulating and documenting professional practice. Journal of Research in Science Teaching, 41(4), 370-391.

Loughran, J., berry, A., \& mullhall, p. (2006). Understanding and developing science teachers' pedagogical content knowledge. Rotterdam, the netherlands: sense publishers.

Loughran, J., mulhall, p., \& berry, A. (2008). Exploring pedagogical content knowledge in science teacher education. International Journal of Science Education, 30(10), 13011320 .

Martinis Yamin. (2008). Desain Pembelajaran Berbasis Tingkat Satuan Pendidikan. Jakarta : Gaung Persada Press.

Rohann, E., taconis, R., \& Jochems, W. (2010). Reviewing the relations between teachers' knowledge and pupils' attitude in the field of primary technology education. International Journal of Technology and Design Education, 20(1), 15-26.

Soedijarto, 2008. Landasan dan Arah Pendidikan Nasional Kita. Jakarta : Kompas

Soegiyono. 2010. Metode Penelitian Pendidikan (Pendekatak Kualitatif, Kuantitatif dan $R \& D)$. Bandung : Alfabeta.

Sukmadinata, Nana syaodih. 2009. Metode Penelitian Pendidikan. Bandung : Remaja Rosdakarya. 


\section{APPENDIX}

\section{CoRe (Content Representation)}

\begin{tabular}{|c|c|c|c|c|c|c|c|}
\hline \multirow[t]{2}{*}{ No. } & \multicolumn{7}{|c|}{$\begin{array}{l}\text { Big Science Concept : Suggestion and Offer } \\
\text { Grade/Semester : XI / } 1 \text { st Semester } \\
\text { Teacher } \quad \text { : Miss. Nanda Eka Yuniarti } \\
\text { Source } \quad \text { : English Handbook/ LKS (Lembar Kerja Siswa) "MODUL PEMBELAJARAN BAHASA INGGRIS" Based on 2013 curriculum } \\
\text { Published by }: \text { Viva Pakariondo }\end{array}$} \\
\hline & Questions & Introduction & $\begin{array}{c}\text { Asking for and } \\
\text { Giving Suggestion } \\
\text { and offer } \\
\end{array}$ & $\begin{array}{l}\text { The Use of Modal } \\
\text { "Should and "Can" }\end{array}$ & $\begin{array}{l}\text { Listening } \\
\text { Skill }\end{array}$ & $\begin{array}{l}\text { Speaking } \\
\text { Skill }\end{array}$ & $\begin{array}{l}\text { Writing } \\
\text { Skill }\end{array}$ \\
\hline 1 & $\begin{array}{l}\text { What you intend the } \\
\text { students to learn about } \\
\text { this idea? }\end{array}$ & $\begin{array}{l}\text { Memperkenalkan } \\
\text { materi Suggestion and } \\
\text { Offer. }\end{array}$ & $\begin{array}{l}\text { Meingidentifikasi } \\
\text { suggestion and offer } \\
\text { expression. }\end{array}$ & $\begin{array}{l}\text { Menganalisis } \\
\text { penggunaan } \\
\text { "Should" dan "Can" }\end{array}$ & $\begin{array}{l}\text { Memahami maksud } \\
\text { suggestion atau } \\
\text { offer oleh audio. }\end{array}$ & $\begin{array}{l}\text { Mengaplikasikan } \\
\text { suggestion and offer } \\
\text { dengan bentuk oral. }\end{array}$ & $\begin{array}{l}\text { Membuat essay atau } \\
\text { memberikan } \\
\text { informasi dengan } \\
\text { menggunakan } \\
\text { expresion. }\end{array}$ \\
\hline 2 & $\begin{array}{l}\text { Why it's important for } \\
\text { the students to know } \\
\text { this? }\end{array}$ & $\begin{array}{l}\text { Siswa dapat memahami } \\
\text { kegunaan dari } \\
\text { suggestion and offer } \\
\text { expression. }\end{array}$ & $\begin{array}{l}\text { Siswa dapat } \\
\text { mengidentifikasi } \\
\text { perbedaan antara } \\
\text { suggestion dan offer. }\end{array}$ & $\begin{array}{l}\text { Siswa mampu } \\
\text { menganalisis } \\
\text { penggunaan modal } \\
\text { expression dalam } \\
\text { kalimat. }\end{array}$ & $\begin{array}{l}\text { Siswa dapat } \\
\text { mendengarkan dan } \\
\text { memahami isi dari } \\
\text { percakapan. }\end{array}$ & $\begin{array}{l}\text { Siswa dapat } \\
\text { mengaplikasikan } \\
\text { expresion of } \\
\text { suggestion and Offer } \\
\text { dalam percakapan } \\
\text { bentuk oral. }\end{array}$ & $\begin{array}{l}\text { Siswa mampu } \\
\text { membuat essay atau } \\
\text { memberikan } \\
\text { informasi dengan } \\
\text { menggunakan } \\
\text { expresion suggestion } \\
\text { and offer. }\end{array}$ \\
\hline 3 & $\begin{array}{l}\text { Teaching procedures ( } \\
\text { and particular reasons } \\
\text { for using these to } \\
\text { engage with this idea) }\end{array}$ & $\begin{array}{l}\text { - } \\
\text { preseption } \\
\text { - Peserta didik dan } \\
\text { guru berdiskusi } \\
\text { mengenai expression } \\
\text { of suggestion and } \\
\text { offer. Pengenalan } \\
\text { materi. }\end{array}$ & $\begin{array}{l}\text {-Aprerseption } \\
\text { - Peserta didik } \\
\text { membuat kelompok } \\
\text { terdiri dari } 2 \text { orang } \\
\text { yang membahas } \\
\text { mengenai asking and } \\
\text { giving suggestion } \\
\text { and offer. } \\
\text { - Peserta didik }\end{array}$ & $\begin{array}{l}\text {-Apreseption } \\
\text { - Peserta didik } \\
\text { diminta membuat } \\
\text { kalimat suggestion } \\
\text { and offer dengan } \\
\text { menggunakan modal. } \\
\text { - guru melemparkan } \\
\text { bola kecil kepada } \\
\text { peserta didik dan } \\
\end{array}$ & $\begin{array}{l}- \\
\text { preseption } \\
- \\
\text { Peserta didik } \\
\text { diminta mengingat } \\
\text { kembali mengenai } \\
\text { suggestion dan } \\
\text { offer. } \\
\end{array}$ & $\begin{array}{l}\text {-Apreseption } \\
\text { - } \\
\text { Pesertadidikdiminta } \\
\text { memutarkan video } \\
\text { yang didownload. } \\
\text { - Inti } \\
\text {-Peserta didik } \\
\text { Diminta untuk } \\
\text { membuat kelompok }\end{array}$ & $\begin{array}{l}\text {-Apreseption } \\
\text { - Peserta didik } \\
\text { diminta membuat } \\
\text { Essay mengenai } \\
\text { kegiatan di } \\
\text { lingkungan sekitar } \\
\text { dan memberikan } \\
\text { Suggestion and Offer } \\
\text { atau solusi dari }\end{array}$ \\
\hline
\end{tabular}




\begin{tabular}{|c|c|c|c|c|c|c|c|}
\hline & & $\begin{array}{l}\text { Pesertadidikdapat } \\
\text { membedakan antara } \\
\text { suggestion dan offer. } \\
\text { Penutup } \\
\text { - } \\
\text { Peserta didik diminta } \\
\text { untuk mencari } \\
\text { contoh ekspresi } \\
\text { suggestion and offer. }\end{array}$ & $\begin{array}{l}\text { diharuskan membuat } \\
\text { percapakan yang } \\
\text { memuat ekspresi } \\
\text { suggestion and offer } \\
\text { dengan } \\
\text { menggunakan } \\
\text { - Penutup }\end{array}$ & $\begin{array}{l}\text { peserta didik } \\
\text { membacakan contoh } \\
\text { expresssion } \\
\text { suggestion dan offer } \\
\text { yang telah dibuat } \\
\text { siswa, lalu siswa } \\
\text { meleparkan kembali } \\
\text { ke guru tersebut, dan } \\
\text { seterusnya. } \\
\text { - Guru } \\
\text { menyimpulkan } \\
\text { pelajaran } \\
\text {-Penutup }\end{array}$ & $\begin{array}{l}\text { uru memutarkan } \\
\text { audio mengenai } \\
\text { suggestion and } \\
\text { offer. } \\
\text { Peserta didik } \\
\text { diminta untuk } \\
\text { memahami } \\
\text { maksuddari audio } \\
\text { yang diputar. } \\
\text { - } \\
\text { Peserta didik } \\
\text { menyimak audio. } \\
\text { - } \\
\text { uru menanyakan } \\
\text { kepada Peserta } \\
\text { didik mengenai } \\
\text { audio yang } \\
\text { diputarkan - } \\
\text { Penutup } \\
\text { - } \\
\text { Peserta didik } \\
\text { diminta } \\
\text { mendownload } \\
\text { video suggestion } \\
\text { and offer dalam } \\
\text { kelompok. }\end{array}$ & $\begin{array}{l}\text { yang berisikan } 2 \\
\text { orang dan membuat } \\
\text { dialog yang } \\
\text { mencakup suggestion } \\
\text { dan offer expression. } \\
\text { - Peserta didik } \\
\text { diminta } \\
\text { menaampilkan dialog } \\
\text { di depan kelas. } \\
\text { - Penutup }\end{array}$ & $\begin{array}{l}\text { permasalahan yang } \\
\text { ada dalam kegiatan } \\
\text { tersebu(max } 5 \\
\text { paragraf). } \\
\text { - Peserta didik } \\
\text { mengumpulkan } \\
\text { karangan. } \\
\text { - Guru menilai hasil } \\
\text { karangan siswa. } \\
\text { - Penutup }\end{array}$ \\
\hline 4 & $\begin{array}{l}\text { Specific ways of } \\
\text { ascertaining students } \\
\text { understanding or } \\
\text { confusion around this } \\
\text { idea? }\end{array}$ & 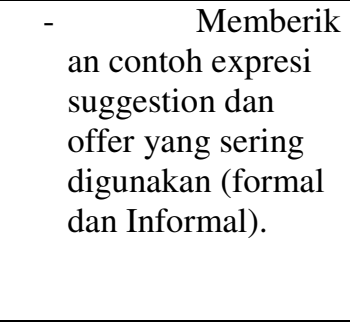 & $\begin{array}{l}\text { - Meemb } \\
\text { erikan teks untuk } \\
\text { dianalisis } \\
\text { penggunaan } \\
\text { ekspresi yang } \\
\text { sesuai dengan } \\
\text { suggestion dan } \\
\text { offer. } \\
\end{array}$ & $\begin{array}{l}\text { - Menany } \\
\text { akan ekspresi } \\
\text { dengan } \\
\text { menggunakan } \\
\text { modal. }\end{array}$ & $\begin{array}{l}\text { - Memper } \\
\text { dengarkan audio } \\
\text { percakapan yang } \\
\text { memuat } \\
\text { suggestion dan } \\
\text { offer. }\end{array}$ & $\begin{array}{l}\text { - Mempr } \\
\text { aktekan } \\
\text { percakapan } \\
\text { melalui dialog } \\
\text { dengan teman } \\
\text { sebangku. }\end{array}$ & 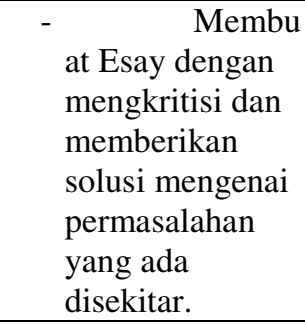 \\
\hline 5 & $\begin{array}{l}\text { What else you might } \\
\text { know about this idea }\end{array}$ & $\begin{array}{ll}\text { Ada } & \text { Tidak } \\
\end{array}$ & $\begin{array}{ll}\text { Ada } & \text { Tidak } \\
\end{array}$ & $\begin{array}{ll}\text { Ada } & \text { Tidak } \\
\end{array}$ & $\begin{array}{ll}\text { Ada } & \text { Tidak } \\
\end{array}$ & $\begin{array}{ll}\text { Ada } & \text { Tidak } \\
\end{array}$ & $\begin{array}{ll}\text { Ada } & \text { Tidak } \\
\end{array}$ \\
\hline
\end{tabular}




\begin{tabular}{|c|c|c|c|c|c|c|c|}
\hline & $\begin{array}{l}\text { (that you don't intend } \\
\text { students to know yet)? }\end{array}$ & & & & & & \\
\hline 6 & $\begin{array}{l}\text { Difficulties/ limitation } \\
\text { connected with } \\
\text { teaching this idea? }\end{array}$ & $\begin{array}{l}\text { - } \quad \text { Siswa } \\
\text { tidak aktif }\end{array}$ & 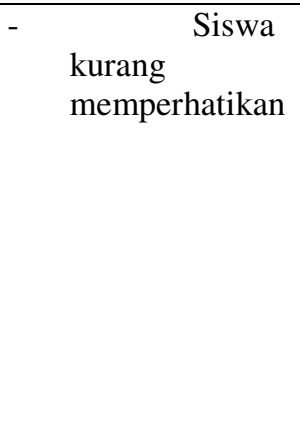 & $\begin{array}{l}\text { - } \quad \text { Siswa } \\
\text { kurang } \\
\text { berpartisipasi. }\end{array}$ & $\begin{array}{l}\text { Keterba } \\
\text { tasan waktu, } \\
\text { karena tingkat } \\
\text { pemahaman dan } \\
\text { fokus } \\
\text { mendengarkan } \\
\text { audio. }\end{array}$ & $\begin{array}{l}\text { - } \\
\text { melafalkan kata } \\
\text { atau kalimat } \\
\text { dengan pelafalan } \\
\text { yang belum } \\
\text { tepat, sehingga } \\
\text { membutuhkan } \\
\text { perbaikan pada } \\
\text { kalimat atau kata } \\
\text { yang dlafalkan } \\
\text { belum tepat. }\end{array}$ & $\begin{array}{l}\text { - } \quad \text { Kurang } \\
\text { nya elaborasi } \\
\text { atau } \\
\text { pengembangan } \\
\text { tulisan yang } \\
\text { dibuat oleh } \\
\text { siswa. }\end{array}$ \\
\hline 7 & $\begin{array}{l}\text { Knowledge about } \\
\text { students' thingking that } \\
\text { influence your teaching } \\
\text { of this idea? }\end{array}$ & - Tidak Ada & - Tidak Ada & - Tidak Ada & $\begin{array}{l}\text { Banyaknya difficult } \\
\text { word dalam } \\
\text { percakapan, pelafalan } \\
\text { (aksen) oleh Native } \\
\text { speakers yang sulit } \\
\text { didengar siswa. }\end{array}$ & $\begin{array}{l}\text { Siswa melafalkan } \\
\text { kata atau kalimat } \\
\text { yang belum tepat. }\end{array}$ & $\begin{array}{l}\text { Kurangnya } \\
\text { vocabulary. }\end{array}$ \\
\hline 8 & $\begin{array}{l}\text { Other factors that } \\
\text { influence your teaching } \\
\text { of this idea. }\end{array}$ & Tidak Ada & Tidak Ada & Tidak Ada & $\begin{array}{l}\text { Kemampuan } \\
\text { mendengar dan daya } \\
\text { tangkap siswa dalam } \\
\text { mendengarkan audio. }\end{array}$ & $\begin{array}{l}\text { Kesalahan dalam } \\
\text { pelafalan dan } \\
\text { intonasi. }\end{array}$ & $\begin{array}{l}\text { Kesulitan dalam } \\
\text { menyusun kalimat } \\
\text { secara koheren dan } \\
\text { komprehensif, } \\
\text { penggunaan } \\
\text { gramatical dan } \\
\text { pengmabangan } \\
\text { tulisan. }\end{array}$ \\
\hline
\end{tabular}




\begin{tabular}{|c|c|c|c|c|c|c|c|}
\hline \multirow[t]{2}{*}{ No. } & \multicolumn{7}{|c|}{ 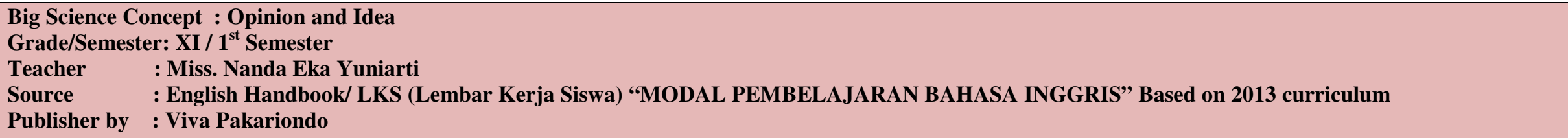 } \\
\hline & Questions & Introduction & $\begin{array}{l}\text { Asking for and } \\
\text { Giving Opinion } \\
\text { and Idea }\end{array}$ & $\begin{array}{c}\text { The Use of Modal "I } \\
\text { think" and "In My } \\
\text { Opinion" }\end{array}$ & $\begin{array}{l}\text { Listening } \\
\text { Skill }\end{array}$ & $\begin{array}{l}\text { Speaking } \\
\text { Skill }\end{array}$ & $\begin{array}{c}\text { Writing } \\
\text { Skill }\end{array}$ \\
\hline 1 & $\begin{array}{l}\text { What you intend the } \\
\text { students to learn about } \\
\text { this idea? }\end{array}$ & $\begin{array}{l}\text { Memperkenalkan } \\
\text { materi Expression } \\
\text { Opinion and Idea . }\end{array}$ & $\begin{array}{l}\text { Meingidentifikasi } \\
\text { giving and idea } \\
\text { expression. }\end{array}$ & $\begin{array}{l}\text { Menganalisis dan } \\
\text { Menggunkaan } \\
\text { penggunaan "I think" } \\
\text { dan "In My opinion" }\end{array}$ & $\begin{array}{l}\text { Memahami maksud } \\
\text { opinion and idea } \\
\text { oleh video yang } \\
\text { diperlihatkan. }\end{array}$ & $\begin{array}{l}\text { Mengaplikasikan } \\
\text { opinion and idea } \\
\text { dengan bentuk oral. }\end{array}$ & $\begin{array}{l}\text { Membuat essay atau } \\
\text { memberikan } \\
\text { informasi dengan } \\
\text { menggunakan } \\
\text { expresion. }\end{array}$ \\
\hline 2 & $\begin{array}{l}\text { Why it's important for } \\
\text { the students to know } \\
\text { this? }\end{array}$ & $\begin{array}{l}\text { Siswa dapat memahami } \\
\text { kegunaan dari } \\
\text { Opinion and Idea } \\
\text { expression. }\end{array}$ & $\begin{array}{l}\text { Siswa dapat } \\
\text { mengidentifikasi } \\
\text { perbedaan antara } \\
\text { opinion dan idea. }\end{array}$ & $\begin{array}{l}\text { Siswa mampu } \\
\text { menganalisis } \\
\text { penggunaan modal } \\
\text { expression dalam } \\
\text { kalimat. }\end{array}$ & $\begin{array}{l}\text { Siswa menyaksikan } \\
\text { video debat bahasa } \\
\text { inggris asia dan } \\
\text { memahami isi dari } \\
\text { penyampaian opini. }\end{array}$ & $\begin{array}{l}\text { Siswa dapat } \\
\text { mengaplikasikan } \\
\text { expresion of opinion } \\
\text { and idea dalam } \\
\text { percakapan bentuk } \\
\text { oral. }\end{array}$ & $\begin{array}{l}\text { Siswa mampu } \\
\text { membuat essay kritik } \\
\text { dan gagasan, } \\
\text { perspektif siswa atau } \\
\text { memberikan } \\
\text { informasi dengan } \\
\text { menggunakan } \\
\text { expresion opinion } \\
\text { and idea. Unutk } \\
\text { melatih critical } \\
\text { thinking dalam } \\
\text { kehidupan sehari-hari } \\
\text { dalam bentuk tulisan. }\end{array}$ \\
\hline 3 & $\begin{array}{l}\text { Teaching procedures ( } \\
\text { and particular reasons } \\
\text { for using these to } \\
\text { engage with this idea) }\end{array}$ & $\begin{array}{l}\text { - } \\
\text { - } \\
\text { Preseption } \\
\text { Peserta didikd an } \\
\text { guru berdiskusi } \\
\text { mengenai expression } \\
\text { of Opinion and Idea. } \\
\text { Pengenalan materi. }\end{array}$ & $\begin{array}{l}\text {-Aprerseption } \\
\text { - Peserta didik } \\
\text { membuat kelompok } \\
\text { terdiri dari } 2 \text { orang } \\
\text { yang membahas } \\
\text { mengenai asking and } \\
\text { giving opinion and } \\
\text { idea. }\end{array}$ & $\begin{array}{l}\text {-Apreseption } \\
\text { - Peserta didik } \\
\text { diminta membuat } \\
\text { kalimat opinion and } \\
\text { idea dengan } \\
\text { menggunakan "I } \\
\text { think" dan "In My } \\
\text { opinion". }\end{array}$ & $\begin{array}{l}\text { - } \\
\text { preseption } \\
\text { - } \\
\text { esertadidikdiminta } \\
\text { mengingatkembali } \\
\text { mengenai opinion } \\
\text { dan idea. } \\
\text { - }\end{array}$ & $\begin{array}{l}\text {-Apreseption } \\
- \\
\text { Pesertadidikdiminta } \\
\text { memutarkan video } \\
\text { yang didownload. } \\
\text { - Inti } \\
\text {-Pesertadidik } \\
\text { Dimintauntukmembu }\end{array}$ & $\begin{array}{l}\text {-Apreseption } \\
\text { - } \\
\text { Pesertadidikdiminta } \\
\text { membuat Essay } \\
\text { mengenaikegiatandili } \\
\text { ngkungansekitardan } \\
\text { memberikangagasan, } \\
\text { pendapat, }\end{array}$ \\
\hline
\end{tabular}




\begin{tabular}{|c|c|c|c|c|c|c|c|}
\hline & & $\begin{array}{l}\text { - } \\
\text { Pesertadidikdapat } \\
\text { membedakan antara } \\
\text { opinion dan idea } \\
\text { expression . } \\
\text { Penutup } \\
\text { - } \\
\text { Peserta didik diminta } \\
\text { untuk mencari } \\
\text { contoh ekspresi } \\
\text { opinion and idea. }\end{array}$ & $\begin{array}{l}\text { - Peserta didik } \\
\text { diharuskan membuat } \\
\text { percapakan yang } \\
\text { memuat ekspresi } \\
\text { opinion and idea } \\
\text { dengan } \\
\text { menggunakan } \\
\text { ekspresi tersebut. } \\
\text { Lalu ditampilkan } \\
\text { didepan kelas. } \\
\text { - Penutup } \\
\text { - Merangkum } \\
\text { kegiatan } \\
\text { pembelajaran yang } \\
\text { telah dilakukan } \\
\text { secara lisan. }\end{array}$ & $\begin{array}{l}\text {-guru memberikan } \\
\text { tugas kepada siswa } \\
\text { untuk bermain } \\
\text { problemsolving } \\
\text { "siswa diberikan } \\
\text { masalah } \\
\text { dilingkungan sekitar } \\
\text { dan siswa diharapkan } \\
\text { mampu mengusulkan } \\
\text { pendapat dalam } \\
\text { bahasa inggris. } \\
\text { Masing-masing siswa } \\
\text { membrikan pendapat. } \\
\text {-Guru menyimpulkan } \\
\text { pelajaran } \\
\text {-Penutup }\end{array}$ & $\begin{array}{l}\text { uru memutarkan } \\
\text { video debat yang } \\
\text { terdapatekspresi } \\
\text { opinion and idea. } \\
\text { esertadidikdiminta } \\
\text { untukmemahamim } \\
\text { aksuddari video } \\
\text { yang diputar. } \\
\text { - } \\
\text { esertadidikmenyim } \\
\text { ak video. } \\
\text { - } \\
\text { Guru } \\
\text { menanyakankepad } \\
\text { aPesertadidikmeng } \\
\text { enai video yang } \\
\text { diputarkan - } \\
\text { Penutup } \\
\text { - } \\
\text { esertadidikdiminta } \\
\text { mendownload } \\
\text { video opinion and } \\
\text { idea } \\
\text { dalamkelompok. }\end{array}$ & $\begin{array}{l}\text { atkelompok yang } \\
\text { berisikan } 2 \text { orang } \\
\text { danmembuat dialog } \\
\text { yang mencakup } \\
\text { opinion dan idea } \\
\text { expression. } \\
\text { - } \\
\text { Pesertadidikdiminta } \\
\text { menaampilkan dialog } \\
\text { di depankelas. } \\
\text { - Penutup }\end{array}$ & $\begin{array}{l}\text { perspektifmengenais } \\
\text { uatuhal. } \\
\text { Denganmenggunaka } \\
\text { nekspresi opinion } \\
\text { and idea } \\
\text { daripermasalahan } \\
\text { yang } \\
\text { adadalamkegiatanters } \\
\text { ebu (max } 5 \text { paragraf). } \\
\text { - } \\
\text { Pesertadidikmengum } \\
\text { pulkankarangan. } \\
\text { - Guru } \\
\text { menilaihasilkarangan } \\
\text { siswadanmengevalua } \\
\text { sihasilsiswa. } \\
\text { - Penutup }\end{array}$ \\
\hline 4 & $\begin{array}{l}\text { Specific ways of } \\
\text { ascertaining students } \\
\text { understanding or } \\
\text { confusion around this } \\
\text { idea? }\end{array}$ & $\begin{array}{l}\text { - } \quad \text { Memberik } \\
\text { an contoh ekpresi } \\
\text { opinion dan idea } \\
\text { yang sering } \\
\text { digunakan (formal } \\
\text { dan Informal). }\end{array}$ & $\begin{array}{l}\text { - Member } \\
\text { ikan teks untuk } \\
\text { dianalisis } \\
\text { penggunaan } \\
\text { ekspresi yang } \\
\text { sesuai dengan } \\
\text { opinion dan idea. }\end{array}$ & $\begin{array}{l}\text { - Member } \\
\text { ikan pendapat } \\
\text { dengan } \\
\text { menggunakan } \\
\text { ekspresi giving } \\
\text { opinion and idea. }\end{array}$ & $\begin{array}{l}\text { - Menam } \\
\text { pilkan video } \\
\text { debat bahasa } \\
\text { inggris asia yang } \\
\text { memuat } \\
\text { penyampaian } \\
\text { opinion dan idea. }\end{array}$ & $\begin{array}{l}\text { - Mempr } \\
\text { aktekan } \\
\text { percakapan } \\
\text { melalui dialog } \\
\text { dengan teman } \\
\text { sebangku. }\end{array}$ & $\begin{array}{l}\text { - } \\
\text { Membuat Esay } \\
\text { dengan } \\
\text { menyatakan } \\
\text { gagasan, } \\
\text { pendapat, } \\
\text { perspektif } \\
\text { mengenai } \\
\text { permasalahan } \\
\text { yang ada } \\
\text { disekitar menurut } \\
\text { pandangan siswa. }\end{array}$ \\
\hline
\end{tabular}




\begin{tabular}{|c|c|c|c|c|c|c|c|}
\hline 5 & $\begin{array}{l}\text { What else you might } \\
\text { know about this idea } \\
\text { (that you don't intend } \\
\text { students to know yet)? }\end{array}$ & $\begin{array}{ll} & \text { Tidak } \\
\text { Ada } & \end{array}$ & $\begin{array}{ll}\text { Ada } & \text { Tidak } \\
\end{array}$ & $\begin{array}{l}-\quad \text { Ekspres } \\
\text { i yang digunakan } \\
\text { untuk } \\
\text { menyampaikan } \\
\text { gagasan dan } \\
\text { usulan yang baik. }\end{array}$ & $\begin{array}{l}\text { - Siswa } \\
\text { untuk mampu } \\
\text { memahami dan } \\
\text { menganalisis } \\
\text { gagasan dari } \\
\text { video. }\end{array}$ & $\begin{array}{ll} & \text { Tidak } \\
\text { Ada } & \end{array}$ & $\begin{array}{ll} & \text { Tidak } \\
\text { Ada } & \end{array}$ \\
\hline 6 & $\begin{array}{l}\text { Difficulties/ limitation } \\
\text { connected with } \\
\text { teaching this idea? }\end{array}$ & $\begin{array}{l}\text { Siswa } \\
\text { yang pasif }\end{array}$ & $\begin{array}{l}\text { kurang } \\
\text { memperhatikan }\end{array}$ & $\begin{array}{l}\text { - } \quad \text { Siswa } \\
\text { kurang } \\
\text { berpartisipasi. }\end{array}$ & $\begin{array}{l}\text { Keterba } \\
\text { tasan waktu, } \\
\text { karena tingkat } \\
\text { pemahaman dan } \\
\text { fokus melihat } \\
\text { dan } \\
\text { mendengarkan } \\
\text { audio/video. }\end{array}$ & $\begin{array}{l}\text { - Siswa } \\
\text { melafalkan kata } \\
\text { atau kalimat } \\
\text { dengan pelafalan } \\
\text { yang belum } \\
\text { tepat, sehingga } \\
\text { membutuhkan } \\
\text { perbaikan pada } \\
\text { kalimat atau } \\
\text { kata. } \\
\end{array}$ & $\begin{array}{l}\text { - } \quad \text { Kurang } \\
\text { nya elaborasi } \\
\text { atau } \\
\text { pengembangan } \\
\text { tulisan yang } \\
\text { dibuat oleh } \\
\text { siswa. }\end{array}$ \\
\hline 7 & $\begin{array}{l}\text { Knowledge about } \\
\text { students' thingking that } \\
\text { influence your teaching } \\
\text { of this idea? }\end{array}$ & - Tidak Ada & - Tidak Ada & - Tidak Ada & $\begin{array}{l}\text { Banyaknya difficult } \\
\text { word dalam } \\
\text { percakapan, pelafalan } \\
\text { (aksen) oleh Native } \\
\text { speakers yang sulit } \\
\text { didengar siswa. } \\
\end{array}$ & $\begin{array}{l}\text { Siswa melafalkan } \\
\text { kata atau kalimat } \\
\text { yang belum tepat. }\end{array}$ & $\begin{array}{l}\text { Kurangnya } \\
\text { vocabulary dan } \\
\text { keadaan kenyataan. }\end{array}$ \\
\hline 8 & $\begin{array}{l}\text { Other factors that } \\
\text { influence your teaching } \\
\text { of this idea. }\end{array}$ & Tidak Ada & Tidak Ada & Tidak Ada & $\begin{array}{l}\text { Kemampuan } \\
\text { mendengar dan daya } \\
\text { tangkap siswa dalam } \\
\text { mendengarkan, } \\
\text { melihat dan } \\
\text { memahami video/ } \\
\text { audio. Faktor } \\
\text { eksternal alat-alat } \\
\text { pendukung (speaker } \\
\text { dan Proyektor). }\end{array}$ & $\begin{array}{l}\text { Kesalahan dalam } \\
\text { pelafalan dan } \\
\text { intonasi. }\end{array}$ & $\begin{array}{l}\text { Kesulitan dalam } \\
\text { menyusun kalimat } \\
\text { secara koheren dan } \\
\text { komprehensif, } \\
\text { penggunaan } \\
\text { gramatical dan } \\
\text { pengembangan } \\
\text { tulisan. }\end{array}$ \\
\hline
\end{tabular}




\begin{tabular}{|c|c|c|c|c|c|c|c|}
\hline \multirow[t]{2}{*}{ No. } & \multicolumn{7}{|c|}{$\begin{array}{l}\text { Big Science Concept : You Are Invited to a Party } \\
\text { Grade/Semester : XI / } 1^{\text {st }} \text { Semester } \\
\text { Teacher } \quad \text { : Miss. Nanda Eka Yuniarti } \\
\text { Source } \quad \text { English Handbook/ LKS (Lembar Kerja Siswa) “MODUL PEMBELAJARAN BAHASA INGGRIS” Based on 2013 curriculum } \\
\begin{array}{l}\text { Published by } \quad: \text { Viva Pakariondo }\end{array}\end{array}$} \\
\hline & Questions & Introduction & Formal Invitation & Inviting Someone & $\begin{array}{c}\text { Listening } \\
\text { Skill }\end{array}$ & $\begin{array}{c}\text { Speaking } \\
\text { Skill }\end{array}$ & $\begin{array}{c}\text { Writing } \\
\text { Skill }\end{array}$ \\
\hline 1 & $\begin{array}{l}\text { What you intend the } \\
\text { students to learn about } \\
\text { this idea? }\end{array}$ & $\begin{array}{l}\text { Memperkenalkan } \\
\text { materi Invitation } \\
\text { (formal invitation dan } \\
\text { informal invitation). } \\
\text { Siswa dapat } \\
\text { membedakan kedua } \\
\text { jenis invitation. }\end{array}$ & $\begin{array}{l}\text { Meingidentifikasi } \\
\text { formal invitation } \\
\text { baik struktur, format } \\
\text { tulisan, dan isi. }\end{array}$ & $\begin{array}{l}\text { Mengundang } \\
\text { seseorang baik dalam } \\
\text { bentuk tulisan dan } \\
\text { lisan. }\end{array}$ & $\begin{array}{l}\text { Memahami maksud } \\
\text { atau memahami isi } \\
\text { undangan atau } \\
\text { invitation. }\end{array}$ & $\begin{array}{l}\text { Mengaplikasikan } \\
\text { invitation dan respon } \\
\text { atau mengundang } \\
\text { seseorang melalui } \\
\text { lisan. }\end{array}$ & $\begin{array}{l}\text { Membuat krreatifitas } \\
\text { surat undangan } \\
\text { sesuai dengan } \\
\text { format. . }\end{array}$ \\
\hline 2 & $\begin{array}{l}\text { Why it's important for } \\
\text { the students to know } \\
\text { this? }\end{array}$ & $\begin{array}{l}\text { Siswa dapat } \\
\text { menganalisis dan } \\
\text { memahami Formal dan } \\
\text { Informal invitation. }\end{array}$ & $\begin{array}{l}\text { Siswa dapat } \\
\text { mengidentifikasi } \\
\text { format penullisan } \\
\text { invitation. }\end{array}$ & $\begin{array}{l}\text { Siswa mampu } \\
\text { membuat dan } \\
\text { mengajak/ } \\
\text { mengundang secara } \\
\text { tulis dan lisan. }\end{array}$ & $\begin{array}{l}\text { Siswa dapat } \\
\text { mendengarkan dan } \\
\text { memahami isi dari } \\
\text { undangan secara } \\
\text { lisan dan langsung. }\end{array}$ & $\begin{array}{l}\text { Siswa dapat } \\
\text { mengaplikasikan } \\
\text { mengundang dalam } \\
\text { bentuk oral. }\end{array}$ & $\begin{array}{l}\text { Siswa mampu } \\
\text { membuat kreatifitas } \\
\text { surat undangan untuk } \\
\text { menerapkan format } \\
\text { dan sistematika } \\
\text { penulisan undangan } \\
\text { sesuai formal atau } \\
\text { informal invitation. }\end{array}$ \\
\hline 3 & $\begin{array}{l}\text { Teaching procedures ( } \\
\text { and particular reasons } \\
\text { for using these to } \\
\text { engage with this idea) }\end{array}$ & $\begin{array}{l}\text { - } \\
\text { preseption } \\
\text { Guru memberikan } \\
\text { beberapa contoh } \\
\text { mengenai formal } \\
\text { invitation dan } \\
\text { informal invitation } \\
\text { melalui slide. } \\
\text { - } \\
\text { Peserta didik dapat } \\
\text { membedakan }\end{array}$ & $\begin{array}{l}\text {-Aprerseption } \\
\text { - Peserta didik } \\
\text { membuat kelompok } \\
\text { terdiri dari } 2 \text { orang } \\
\text { yang membuat surat } \\
\text { secara formal, dan } \\
\text { memberikan kepada } \\
\text { siswa pasangannya } \\
\text { untuk diidentifikasi } \\
\text { dan dievaluasi } \\
\text { bersama. } \\
\text { - Guru memberikan }\end{array}$ & $\begin{array}{l}\text {-Apreseption } \\
\text { - Peserta didik } \\
\text { diminta membuat } \\
\text { surat undangan } \\
\text { kepada temannya } \\
\text { sesuai tema yang } \\
\text { diberikan guru. } \\
\text {-guru mengevaluasi } \\
\text { hasil siswa. } \\
\text { - Guru } \\
\text { menyimpulkan } \\
\text { pelajaran }\end{array}$ & $\begin{array}{l}\text { - } \\
\text { preseption } \\
\text { - } \\
\text { esertadidikdiminta } \\
\text { mengingatkembali } \\
\text { mengenai } \\
\text { invitation. } \\
\text { - } \\
\text { uru memutarkan } \\
\text { audio } \\
\text { mengenaiinvittaion } \\
\text {. }\end{array}$ & $\begin{array}{l}\text {-Apreseption } \\
\text { - } \\
\text { Pesertadidikdiminta } \\
\text { membuatkelompok, } \\
\text { masing- } \\
\text { masingkelompokberj } \\
\text { umlah } 3 \text { orang. } \\
\text { - Masing- } \\
\text { masingkelompokdim } \\
\text { intamembuat video } \\
\text { mengundangatau } \\
\text { inviting someone }\end{array}$ & $\begin{array}{l}\text {-Apreseption } \\
\text { - } \\
\text { Pesertadidikdiminta } \\
\text { membuatmengambilf } \\
\text { ishballatauundiansuat } \\
\text { undangan yang } \\
\text { akandibuat (formal } \\
\text { atau informal). } \\
\text { - } \\
\text { Pesertadidikdiminta } \\
\text { membuatkreatifitasu } \\
\text { ndangansesuai yang }\end{array}$ \\
\hline
\end{tabular}




\begin{tabular}{|c|c|c|c|c|c|c|c|}
\hline & & $\begin{array}{l}\text { perbedaan format } \\
\text { keduajenis invitation } \\
\text { tersebut. } \\
\text { Penutup } \\
\text { - } \\
\text { Peserta didik diminta } \\
\text { untuk mencari } \\
\text { contoh formal } \\
\text { invitation dan } \\
\text { informal invitation. }\end{array}$ & $\begin{array}{l}\text { evaluasi objektif } \\
\text { hasil formal } \\
\text { invitation siswa. } \\
\text { - Penutup }\end{array}$ & -Penutup & $\begin{array}{l}\text { - } \\
\text { Pesertadidikdimint } \\
\text { a untuk memahami } \\
\text { maksud dari } \\
\text { invitation audio } \\
\text { yang diputar. } \\
\text { - } \\
\text { Pesertadidik } \\
\text { menyimak audio. } \\
\text { - } \\
\text { Guru menanyakan } \\
\text { kepada Peserta } \\
\text { didik mengenai isi } \\
\text { audio yang } \\
\text { diputarkan - } \\
\text { Penutup } \\
\text { - } \\
\text { Peserta didik } \\
\text { diminta } \\
\text { mendownload } \\
\text { video invitation } \\
\text { dalam kelompok. }\end{array}$ & $\begin{array}{l}\text { laludiunggahdalamak } \\
\text { unyoutubeaatau blog } \\
\text { yang } \\
\text { dimilikisetoiapkelom } \\
\text { pok. } \\
\text { - Guru memutarkan } \\
\text { video yang } \\
\text { dibuatsiswadandieval } \\
\text { uasibersamabaik } \\
\text { guru dansiswa. } \\
\text { - Penutup }\end{array}$ & $\begin{array}{l}\text { diperolehmelaluiundi } \\
\text { an. . } \\
\text { - Guru } \\
\text { menilaihasilsuratund } \\
\text { angaansiswa. } \\
\text { - Penutup }\end{array}$ \\
\hline 4 & $\begin{array}{l}\text { Specific ways of } \\
\text { ascertaining students } \\
\text { understanding or } \\
\text { confusion around this } \\
\text { idea? }\end{array}$ & $\begin{array}{l}\text { - Memberik } \\
\text { an contoh formal } \\
\text { dan informal } \\
\text { invitation dalam } \\
\text { bentuk real atau } \\
\text { contoh gambar. }\end{array}$ & $\begin{array}{l}\text { Meemb } \\
\text { erikan contoh } \\
\text { formal invittaion } \\
\text { untuk dianalisis. }\end{array}$ & $\begin{array}{l}\text { Mengun } \\
\text { dang seseorang } \\
\text { dalam bentuk } \\
\text { tulisan dan lisan. }\end{array}$ & $\begin{array}{l}\text { - Memper } \\
\text { dengarkan audio } \\
\text { percakapan } \\
\text { invitation atau } \\
\text { mengundang } \\
\text { seseorang. }\end{array}$ & $\begin{array}{l}\text { - Mempr } \\
\text { aktekan } \\
\text { mengundang } \\
\text { atau inviting } \\
\text { someone melalui } \\
\text { dialog dengan } \\
\text { kelompok. }\end{array}$ & $\begin{array}{l}\text { - Mengek } \\
\text { sploari bakat } \\
\text { siswa dalam } \\
\text { kreatifitas } \\
\text { menulis } \\
\text { undangan. }\end{array}$ \\
\hline 5 & $\begin{array}{l}\text { What else you might } \\
\text { know about this idea } \\
\text { (that you don't intend } \\
\text { students to know yet)? }\end{array}$ & ${ }^{-}$Ada & ${ }^{-}$Ada $\quad$ Tidak & ${ }^{-}$Ada Tidak & ${ }^{-}$Ada $\quad$ Tidak & - Ada & Ada $\quad$ Tidak \\
\hline 6 & $\begin{array}{l}\text { Difficulties/ limitation } \\
\text { connected with } \\
\text { teaching this idea? }\end{array}$ & 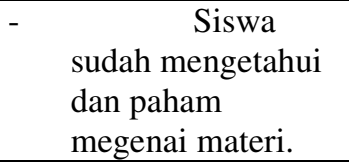 & 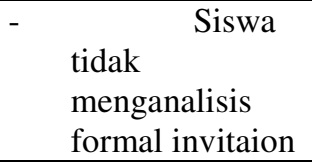 & $\begin{array}{l}\text { Siswa } \\
\text { kurang } \\
\text { berpartisipasi. }\end{array}$ & $\begin{array}{l}\text { Keterba } \\
\text { tasan waktu, } \\
\text { karena tingkat } \\
\text { pemahaman dan }\end{array}$ & 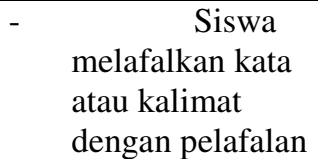 & $\begin{array}{l}\text { Kurang } \\
\text { nya kemampuan } \\
\text { atau kreatifitas } \\
\text { siswa dalam }\end{array}$ \\
\hline
\end{tabular}




\begin{tabular}{|c|c|c|c|c|c|c|c|}
\hline & & & yang diberikan. & & $\begin{array}{l}\text { fokus } \\
\text { mendengarkan } \\
\text { audio. }\end{array}$ & $\begin{array}{l}\text { yang belum } \\
\text { tepat, sehingga } \\
\text { membutuhkan } \\
\text { perbaikan pada } \\
\text { kalimat atau kata } \\
\text { yang dlafalkan } \\
\text { belum tepat. }\end{array}$ & membuat surat. \\
\hline 7 & $\begin{array}{l}\text { Knowledge about } \\
\text { students' thingking that } \\
\text { influence your teaching } \\
\text { of this idea? }\end{array}$ & - Tidak Ada & - Tidak Ada & - Tidak Ada & $\begin{array}{l}\text { Banyaknya difficult } \\
\text { word dalam } \\
\text { percakapan, pelafalan } \\
\text { (aksen) oleh Native } \\
\text { speakers yang sulit } \\
\text { didengar siswa. }\end{array}$ & $\begin{array}{l}\text { Siswa melafalkan } \\
\text { kata atau kalimat } \\
\text { yang belum tepat. }\end{array}$ & Tidak Ada. \\
\hline 8 & $\begin{array}{l}\text { Other factors that } \\
\text { influence your teaching } \\
\text { of this idea. }\end{array}$ & Tidak Ada & Tidak Ada & Tidak Ada & $\begin{array}{l}\text { Kemampuan } \\
\text { mendengar dan daya } \\
\text { tangkap siswa dalam } \\
\text { mendengarkan audio. }\end{array}$ & $\begin{array}{l}\text { Kesalahan dalam } \\
\text { pelafalan, hafalan } \\
\text { dan intonasi. }\end{array}$ & $\begin{array}{l}\text { Kesulitan dalam } \\
\text { membuat konsep } \\
\text { kerajinan surat } \\
\text { undangan. }\end{array}$ \\
\hline
\end{tabular}




\begin{tabular}{|c|c|c|c|c|c|c|c|}
\hline \multirow[t]{2}{*}{ No. } & \multicolumn{7}{|c|}{$\begin{array}{l}\text { Big Science Concept : An Exposition About Pollution } \\
\text { Grade/Semester : XI / } 1 \text { st Semester } \\
\text { Teacher } \quad \text { : Miss. Nanda Eka Yuniarti } \\
\text { Source } \quad \text { English Handbook/ LKS (Lembar Kerja Siswa) “MODUL PEMBELAJARAN BAHASA INGGRIS” Based on 2013 curriculum } \\
\text { Published by : Viva Pakariondo }\end{array}$} \\
\hline & Questions & Introduction & $\begin{array}{l}\text { Analytical } \\
\text { Expotsition }\end{array}$ & $\begin{array}{c}\text { Langage Features of } \\
\text { Analytical } \\
\text { Exposition }\end{array}$ & $\begin{array}{l}\text { Listening } \\
\text { Skill }\end{array}$ & $\begin{array}{l}\text { Speaking } \\
\text { Skill }\end{array}$ & $\begin{array}{c}\text { Writing } \\
\text { Skill }\end{array}$ \\
\hline 1 & $\begin{array}{l}\text { What you intend the } \\
\text { students to learn about } \\
\text { this idea? }\end{array}$ & $\begin{array}{l}\text { Memperkenalkan } \\
\text { materi jenis teks } \\
\text { eksposisi atau An } \\
\text { exposition. }\end{array}$ & $\begin{array}{l}\text { Memahami general } \\
\text { sturctures of } \\
\text { analytical } \\
\text { exposition. . }\end{array}$ & $\begin{array}{l}\text { Menggunakan } \\
\text { ekspresi sesuai } \\
\text { dengan konteks isi } \\
\text { dalam analytical } \\
\text { exposition. }\end{array}$ & $\begin{array}{l}\text { Memahami maksud } \\
\text { atau memahami } \\
\text { topik yang } \\
\text { diceritakan. }\end{array}$ & $\begin{array}{l}\text { Mengaplikasikan } \\
\text { language features } \\
\text { dalam bentuk lisan. }\end{array}$ & $\begin{array}{l}\text { Membuat essay } \\
\text { analytical exposition } \\
\text { sesuai dengan } \\
\text { format.(general } \\
\text { structure dan } \\
\text { language features). }\end{array}$ \\
\hline 2 & $\begin{array}{l}\text { Why it's important for } \\
\text { the students to know } \\
\text { this? }\end{array}$ & $\begin{array}{l}\text { Siswa dapat } \\
\text { menganalisis dan } \\
\text { memahami teks } \\
\text { ekxposisi . }\end{array}$ & $\begin{array}{l}\text { Siswa dapat } \\
\text { mengidentifikasi } \\
\text { format penullisan } \\
\text { analytical exposition. }\end{array}$ & $\begin{array}{l}\text { Siswa mampu } \\
\text { menggunakan } \\
\text { language features of } \\
\text { analytical exposition. }\end{array}$ & $\begin{array}{l}\text { Siswa dapat } \\
\text { mendengarkan dan } \\
\text { memahami topik dari } \\
\text { percakapan atau } \\
\text { speech, opinion dan } \\
\text { respon mengenai } \\
\text { suatu hal. }\end{array}$ & $\begin{array}{l}\text { Siswa dapat } \\
\text { mengaplikasikan } \\
\text { konsep analytical } \\
\text { exposition dalam } \\
\text { bentuk oral. }\end{array}$ & $\begin{array}{l}\text { Siswa mampu } \\
\text { membuat kreatifitas } \\
\text { tulisan dengan } \\
\text { menerapkan format } \\
\text { dan sistematika } \\
\text { penulisan yang } \\
\text { sesuai. }\end{array}$ \\
\hline 3 & $\begin{array}{l}\text { Teaching procedures ( } \\
\text { and particular reasons } \\
\text { for using these to } \\
\text { engage with this idea) }\end{array}$ & $\begin{array}{l}- \\
\text { - } \\
\text { preseption } \\
\text { Guru memberikan } \\
\text { beberapacontohmeng } \\
\text { enai teks eksposisi. } \\
\text { - } \\
\text { Pesertadidik } \\
\text { memahami dan } \\
\text { mengidentifikasi } \\
\text { tekseksposisi. } \\
\text { Penutup } \\
-\end{array}$ & $\begin{array}{l}\text {-Aprerseption } \\
\text { - Guru memberikan } \\
\text { penjelasan mengenai } \\
\text { teks analytical } \\
\text { exposition kepada } \\
\text { peserta didik. } \\
\text { - Guru dan peserta } \\
\text { didik saling tanya } \\
\text { jawab. } \\
\text { - Penutup } \\
\text { Siswa diminta } \\
\text { mencari contoh } \\
\text { analytical exposition }\end{array}$ & $\begin{array}{l}\text {-Apreseption } \\
\text { - Peserta didik } \\
\text { diminta mencari } \\
\text { language features of } \\
\text { analytical exposition } \\
\text { dan mencoba } \\
\text { membuat layout } \\
\text { tulisan analytical } \\
\text { exposition. } \\
\text {-guru mengevaluasi } \\
\text { hasil siswa. } \\
\text {-Guru menyimpulkan } \\
\text { pelajaran }\end{array}$ & $\begin{array}{l}\text { - } \\
\text { preseption } \\
\text { - } \\
\text { Pesertadidikdimint } \\
\text { amengingatkembal } \\
\text { imengenai } \\
\text { analytical } \\
\text { exposition. } \\
\text { - } \\
\text { Guru memutarkan } \\
\text { audio mengenai } \\
\text { analytical } \\
\text { exposition. }\end{array}$ & $\begin{array}{l}\text {-Apreseption } \\
\text { - } \\
\text { Pesertadidikdiminta } \\
\text { membuatkelompok, } \\
\text { masing- } \\
\text { masingkelompokberj } \\
\text { umlah } 3 \text { orang. } \\
\text { - Masing-masing } \\
\text { kelompokdiminta } \\
\text { membuat video } \\
\text { mengneai kejadian } \\
\text { yang ada di sekitar } \\
\text { lalu diunggah dalam }\end{array}$ & $\begin{array}{l}\text {-Apreseption } \\
\text { - } \\
\text { Pesertadidikdiminta } \\
\text { membuat essay } \\
\text { sesuaidenganminatsis } \\
\text { waakanperistiwa } \\
\text { - Guru menilaihasil } \\
\text { essay siswa. } \\
\text { - Penutup }\end{array}$ \\
\hline
\end{tabular}




\begin{tabular}{|c|c|c|c|c|c|c|c|}
\hline & & $\begin{array}{l}\text { Pesertadidikdiminta } \\
\text { untuk membuat teks } \\
\text { eksposisi. }\end{array}$ & $\begin{array}{l}\text { dari berbagai sumber } \\
\text { (web, internet) dan } \\
\text { memplot-plotkan } \\
\text { sesuai dengan } \\
\text { general structures. }\end{array}$ & -Pепитир & $\begin{array}{l}\text { Pesertadidik } \\
\text { diminta untuk } \\
\text { memahami maksud } \\
\text { dari percakapan } \\
\text { audio yang diputar. } \\
\text { - } \\
\text { Pesertadidik } \\
\text { menyimak audio. } \\
\text { - } \\
\text { Guru menanyakan } \\
\text { kepada Peserta } \\
\text { didik mengenai } \\
\text { isi/topik audio } \\
\text { yang diputarkan - } \\
\text { Penutup } \\
\text { - } \\
\text { Peserta didik } \\
\text { diminta } \\
\text { mendownload } \\
\text { video analytical } \\
\text { exposition dalam } \\
\text { kelompok. }\end{array}$ & $\begin{array}{l}\text { akun youtubea atau } \\
\text { blog yang dimiliki } \\
\text { setiap kelompok. } \\
\text { - Guru memutarkan } \\
\text { video yang dibuat } \\
\text { siswa dan dievaluasi } \\
\text { bersama baik guru } \\
\text { dan siswa. } \\
\text { - Penutup }\end{array}$ & \\
\hline 4 & $\begin{array}{l}\text { Specific ways of } \\
\text { ascertaining students } \\
\text { understanding or } \\
\text { confusion around this } \\
\text { idea? }\end{array}$ & $\begin{array}{l}\text { - Memberik } \\
\text { an contoh teks } \\
\text { eksposisi . }\end{array}$ & \begin{tabular}{ll} 
- & \multicolumn{1}{c}{ Melatih } \\
siswa & \\
mengidentifikasi \\
bagian-bagian \\
teks sesuai \\
dengan general \\
structures. . \\
\end{tabular} & $\begin{array}{l}\text { Menggu } \\
\text { nakan language } \\
\text { festures of } \\
\text { analytical } \\
\text { exposition yang } \\
\text { sesuai dalam } \\
\text { kalimat. }\end{array}$ & $\begin{array}{l}\text { - Memper } \\
\text { dengarkan audio } \\
\text { percakapan } \\
\text { membahas suatu } \\
\text { hal mengenai } \\
\text { polusi. }\end{array}$ & $\begin{array}{l}\text { - Mempr } \\
\text { aktekan teks } \\
\text { analytical } \\
\text { exposition dalam } \\
\text { bentuk lisan pada } \\
\text { kelompok. }\end{array}$ & $\begin{array}{l}\text { - Mengek } \\
\text { sploari bakat } \\
\text { siswa dalam } \\
\text { kreatifitas } \\
\text { menulis } \\
\text { analyticacl } \\
\text { exposition. }\end{array}$ \\
\hline 5 & $\begin{array}{l}\text { What else you might } \\
\text { know about this idea } \\
\text { (that you don't intend } \\
\text { students to know yet)? }\end{array}$ & ${ }^{-}$Ada Tidak & $\begin{array}{l}\text { - Siswa } \\
\text { lebih aktif dan } \\
\text { kritis lingkungan } \\
\text { sekitar dengan } \\
\text { jenis teks } \\
\text { analytical } \\
\text { exposition. }\end{array}$ & ${ }^{-}$Ada Tidak & ${ }^{-}$Ada Tidak & ${ }^{-}$Ada Tidak & - Ada \\
\hline
\end{tabular}




\begin{tabular}{|c|c|c|c|c|c|c|c|}
\hline 6 & $\begin{array}{l}\text { Difficulties/ limitation } \\
\text { connected with } \\
\text { teaching this idea? }\end{array}$ & \begin{tabular}{lc}
\multicolumn{1}{c}{ Siswa } \\
sulit memahami \\
mengenai materi.
\end{tabular} & $\begin{array}{l}\text { - Siswa } \\
\text { tidak } \\
\text { menganalisis } \\
\text { bacaan dengan } \\
\text { cermat. }\end{array}$ & 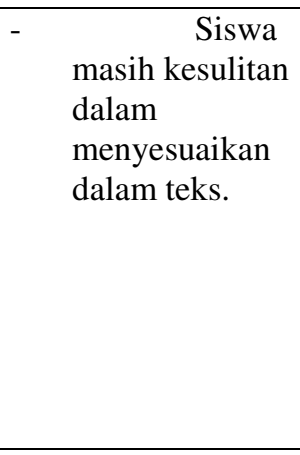 & $\begin{array}{l}\text { Keterba } \\
\text { tasan waktu, } \\
\text { karena tingkat } \\
\text { pemahaman dan } \\
\text { fokus } \\
\text { mendengarkan } \\
\text { audio. }\end{array}$ & 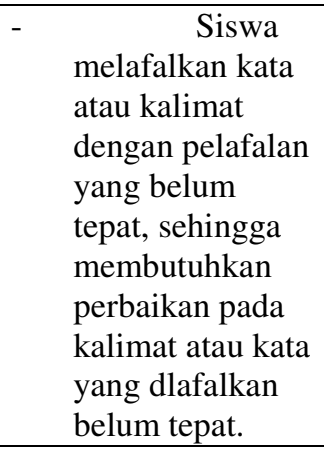 & $\begin{array}{l}\text { Kurang } \\
\text { nya kemampuan } \\
\text { atau kreatifitas } \\
\text { siswa dalam } \\
\text { membuat tulisan } \\
\text { dan koheren. }\end{array}$ \\
\hline 7 & $\begin{array}{l}\text { Knowledge about } \\
\text { students' thingking that } \\
\text { influence your teaching } \\
\text { of this idea? }\end{array}$ & - Tidak Ada & $\begin{array}{l}\text { - meningkatkan daya } \\
\text { kritis siswa melalui } \\
\text { tulisan. }\end{array}$ & - Tidak Ada & $\begin{array}{l}\text { Banyaknya difficult } \\
\text { word dalam } \\
\text { percakapan, pelafalan } \\
\text { (aksen) oleh Native } \\
\text { speakers yang sulit } \\
\text { didengar siswa. }\end{array}$ & $\begin{array}{l}\text { Siswa melafalkan } \\
\text { kata atau kalimat } \\
\text { yang belum tepat. }\end{array}$ & Tidak Ada. \\
\hline 8 & $\begin{array}{l}\text { Other factors that } \\
\text { influence your teaching } \\
\text { of this idea. }\end{array}$ & Tidak Ada & $\begin{array}{l}\text { Siswa kesulitan } \\
\text { membuat karangan. }\end{array}$ & Tidak Ada & $\begin{array}{l}\text { Kemampuan } \\
\text { mendengar dan daya } \\
\text { tangkap siswa dalam } \\
\text { mendengarkan audio. }\end{array}$ & $\begin{array}{l}\text { Kesalahan dalam } \\
\text { pelafalan, hafalan } \\
\text { dan intonasi. }\end{array}$ & $\begin{array}{l}\text { Kesulitan dalam } \\
\text { merangkai kalimat. }\end{array}$ \\
\hline
\end{tabular}

